Journal of Qualitative Criminal Justice \& Criminology

\title{
Forced to Learn: \\ Community-based \\ Correctional Education
}

Ron Mottern ${ }^{1}$, C. Amelia Davis' ${ }^{1}$, Mary F. Ziegler

${ }^{1}$ University of Tennessee

Published on: Oct 01, 2013

DOI: 10.21428/88de04a1.88de8c1c

License: Creative Commons Attribution 4.0 International License (CC-BY 4.0). 


\begin{abstract}
Community-based correctional education has received scant attention in adult literacy research yet mandatory education is a growing part of the legal system and is fueled by research that suggests a link between correctional education and lower rates of recidivism. Growth in alternative to prison programs affects local $\mathrm{ABE}$ and GED programs. Adults who attend community-based correctional programs as a condition of their probation or parole face many challenges. The purpose of this existential-phenomenological study was to understand the experience of those adults. Findings describe students' experiences of being forced to attend a GED program. Opening a space for these stories may help adult educators in community-based programs improve their practice by understanding how students experience the GED program.
\end{abstract}

\title{
Introduction
}

In 2011, close to 7 million adults in the United States were under the supervision of the adult correctional system; this includes offenders held in the custody of state and federal prisons or local jails and those under the supervision of probation and parole agencies. One in 50 adults is currently on probation or parole in this country (Glaze \& Parks, 2012). Approximately $40 \%$ of those on probation and parole lack high school credentials (U.S. Department of Education, 2011). Although communitybased correctional programs take different forms depending on the state, all programs give offenders who are on probation or parole the opportunity to serve their sentences outside of prison under supervision in the local community. For this privilege, they are required to follow the judge's orders and meet the conditions of correctional supervision by court; one condition may be attending adult basic education (ABE) or General Educational Development (GED) classes (Bahn \& Davis, 1998). If offenders violate the conditions of the probation or parole, they face new sanctions and even incarceration.

The growing trend for community-based corrections education in the United States is fueled in part by research that suggests a link between GED attainment and lower rates of recidivism among offenders (Anderson, 1995; Brewster \& Sharp, 2002; Case, 2006; Gehring, 2000; Gordon \& Weldon, 2003; Nuttall, 2003). Although there is a robust body of literature that addresses the experience of incarcerated individuals in educational programs, much less is known about the experiences of individuals who participate in educational programs in community-based corrections (Mageehon, 2003; Moeller, Day, \& Rivera, 2004). Incarcerated adults are captive audiences for educational programs, while those who are in community-based corrections programs (e.g., a day reporting center, halfway house, probation, parole) face distractions not faced by those in a correctional facility (Davis, Mottern \& Ziegler, 2010). Individuals in community-based corrections live at home, are responsible for working or finding 
employment, paying bills, and dealing with transportation. At the same time, many are "forced" to attend $A B E$ or GED classes in order to remain out of prison.

Although participation in community-based correctional ABE and GED programs is growing, there is no credible data on the educational levels of adult students in these programs (Crayton \& Neusteter, n.d), nor is there significant research that addresses the experience of adult students in community correctional settings (Marion, 2002) The problem regarding the lack of research that exists is that this is a growing population in community corrections (Crime and Justice Institute, 2009) and, by extension, correctional education opportunities are increasing (U. S. Department of Education, 2011); this is not being included in literature from the field. Because community corrections are communitybased operations, there is no national clearinghouse for research in regard to this population, and data often become effectively invisible if even considered. As an invisible segment of society, the needs and experiences of the population may be overlooked in community corrections programming. Because we believe the needs and experiences of these learners should be addressed, we have begun looking at this population and their experiences. Therefore, the purpose of this study is to understand the experiences of adults who are required to attend GED classes in a community-based correctional education program. Findings may shed light on an area of educational practice and on a group of students who have received very little attention by the research community.

Since there are no outstanding studies on this correctional population, findings may contribute to the field of corrections by providing insight into the lived experiences of program participants and addressing the ongoing debate of the usefulness of mandatory education in community corrections settings. Since budgetary constraints are a constant issue in correctional programming, data on the effectiveness of forced educational participation may prove useful in determining whether scarce monies are wisely spent in this area.

\section{Theoretical framework}

The orienting framework for this study is existential hermeneutic phenomenology, derived from the work of Heidegger (1962), Husserl (2001), and Merleau-Ponty (2002), because of its focus on understanding the essence of experience. In this study, we define phenomenology as the combination of a philosophy and method, "the philosophical lens of existentialism and the hermeneutic methodology of interpretive phenomenology" (Mottern, 2011, p. 10). The interest of phenomenological research is the lived experience of a particular phenomenon. It assumes that there is an essence or essences to shared experience (Van Manen, 1990) that emphasize the "directional nature of human experience" (Thomas \& Pollio, 2002, p. 14) and acknowledge the interconnectedness between the person and the world that results in the person and the world co-constructing one another. Yochelson and Samenow's (1976) 10-year study of the criminal personality is perhaps the first major work to use phenomenology to study correctional populations. Since then, phenomenology has become an 
established research method within corrections (Frank, Omstead \& Pigg, 2012; Guy, 2005; Nethavhani, 2002; Sayko, 2005; West, 2011; Woods, 2010).

\section{Mandatory education}

It is important to give context to this research and provide background regarding community-based corrections and community-based correctional education. Drawing from adult education and corrections literature, we have chosen to concentrate on what we consider to be the most salient information related to our research.

Mandatory education refers to the legal mandate to attend an educational program including $A B E$ and GED classes. Participants in this study have been referred to GED classes through some aspect of therapeutic jurisprudence (Casey \& Rottman, 2000) and the correctional process, either as a court order or as an order of a probation or parole officer. Mandatory education is used synonymously with involuntary education or legally coerced education, terms commonly used in corrections literature.

While humanistic tendencies may drive educational programs in facilities not hampered by the requirement to validate programmatic expenditures to oversight boards, the lower recidivism rate of ex-offenders who participated in education programs (Jensen \& Reed, 2007; Nuttall, 2003; Roy, 2004; Steurer \& Smith, 2003; Zgoba, Haugebrook, \& Jenkins, 2008) have fueled the creation of mandatory education policies in state correctional facilities. Studies by Andrews and Bonta $(1995,2001,2006)$ and others (Andrews, Bonta \& Wormith, 2000; Aos, 1998; Bonta, 1996; Bonta \& Andrews, 2007; Folsom \& Atkinson, 2007), show that addressing criminogenic needs such as education reduces recidivism. This research has led to the creation of the integrated model of effective intervention in community corrections (Crime and Justice Institute, 2009), as cost-effective evidence-based practices begin to displace less objective measurements of success. It has also been noted that education is seen by community corrections officers as an important aspect of offender re-entry (Gunnison \& Helfgott, 2011; Helfgott \& Gunnison, 2008; Puloka, 2012).

However, while this research represents a new direction of study with community corrections populations, there has been debate surrounding mandatory education programs in prison and courtordered education imposed with sentencing (Coley \& Barton, 2006; Ryan \& McCabe, 1994). One group of experts claim that mandatory education increases the desire for more productive citizenship and potential educational attainment while others view mandatory education programs as costing money and resources that many states do not have (Di Vito, 1991) and stand firm on the idea that educational success can only be achieved through voluntary participation (Jenkins, 2002; Ryan \& McCabe, 1994). As Mottern (2011) states, "Although the courts can mandate attendance at educational classes, they cannot make students learn" (p. 25). 
Regardless of the controversy surrounding mandatory education in state correctional facilities, mandating education as a requirement has spread to community-based correctional programs, and these programs are growing. Adult education has long held that adult learners are voluntary participants in the educational process (Knowles, 1973); however, some researchers indicate that mandatory participation in treatment is often more effective than voluntary participation due to the mandatory nature of attendance (Rempel \& Destefano, 2001; Siddall \& Conway, 1988). Arguments suggesting that mandated attendance is paternalistic and undermines the agency of adult learners do not take into account the research indicating that coerced learners often have positive outcomes (Landenberger \& Lipsey, 2005; Mackenzie, 2000; Wilson, Bouffard \& Mckenzie, 2005). This calls into question the assumption that adult learning must be voluntary in nature.

\section{The correctional student}

Although correctional education is often considered a subset of adult education, there are stark differences between the two which separates them as fields of practice. One of these differences is the view of the student. Adult education and adult learning theory tend to view the optimal setting for education as one in which the learner is an initiator and co-facilitator of the learning. Those who practice in correctional education settings are aware that students must work within the constraints of the system. Encouragement for students more often centers around attainment of subject matter proficiency than overturning established correctional definitions of power. The view of the student as one who shares power within the system versus the view of the student as one who must work within the power constraints of the system, often differentiates non-correctional from correctional practice.

The correctional view that students within the system are somehow different from students outside the system is justified by the evidence-based research (Crime and Justice Institute, 2009). The literature dealing with correctional clients has been well researched for over 30 years and is known as the what works literature (Chavez \& Dawe, 2007; Harper \& Chitty, 2005; Hollin, 1999; Kennedy, 2000; MacKenzie, 2000; Sherman et al., 1998; Wilson, Bouffard, \& Mackenzie, 2005), and includes evidencebased research. This research indicates that individuals within the correctional system think differently than non-correctional individuals (Andrews et al., 1990; Chavaria, 1997; Gendreau, Little, \& Goggin, 1996; Hubbard \& Latessa, 2004; Landenberger \& Lipsey, 2005), and this thinking may eventually result in behaviors that lead these individuals into the correctional system and on probation or parole. According to the what works literature, these patterns of thinking and behavior do not end at the gate of the correctional facility but are carried into the community classroom.

Correctional students are different from non-correctional students in several other ways, some of which may be invisible to educators. Collier and Thomas (2001) stress that correctional students are more linguistically and culturally diverse than students who are not incarcerated. Sohn (2002) indicates that students in correctional institutions tend to have higher levels of emotional and 
behavioral problems than community norms and often come from disadvantaged socioeconomic backgrounds. This is exemplified in an Australian study (Butler et al., 2006) which indicated the prevalence of mental disorders in a prison sample to be $80 \%$, compared with $31 \%$ in a community sample. Studies by Montross and Montross (1997) show that adult incarcerated students place differently on Piaget's and Kohlberg's stages of development than students who are not incarcerated.

Based on what is known from evidence-based practice (Gornik, 2002; Little, Robinson \& Burnette, 1994), it is unlikely that students who have a history of lack of participation in education before becoming a part of the correctional system will suddenly embrace education as a means to turn their lives around, unless it is recognized that the very patterns of thinking that rejected education as a means to success and that placed them within the system are somehow changed. While noncorrectional education has concerned itself with issues such as equity, correctional education has focused on evidence-based research literature and how to apply it in correctional educational settings.

\section{Limitations of phenomenological research}

Limitations in phenomenological research are significantly different from limitations in positivisticoriented research. Phenomenology is concerned with discovering the essence of the phenomenon under consideration, in this case, the experience of community corrections students mandated to attend educational classes. Some limitations in phenomenological research, in general, include the lack of communicative skills by the participants (Tordes \& Holloway, 2010). Willig (2007) has suggested that language, itself, can be a limitation, for a like reason, i.e., the ability to communicate is essential to the interviewing process. Since it is the pre-reflective Lifeworld of the participant that is being studied, the ability of the participant to effectively communicate that experience is always a matter of concern. Limitations such as these are addressed within the phenomenological method by patiently probing participant responses in an effort to obtain rich, thick description. Consensual understanding is sought by rewording and repeating answers to participants until they agree that what the researcher is stating is what they are trying to convey.

\section{Method}

As co-researchers, we collaboratively designed the study, collected data, and completed the data analysis, drawing on our professional experiences as both correctional and non-correctional $\mathrm{ABE}$ and GED practitioners. Existential phenomenology has grown as a qualitative research method (Creswell, 2007; Merriam, 2009), and we chose to use a particular method of analysis developed by Thomas and Pollio (2002) which draws from the work of Merleau-Ponty (2002) and is solidly based on a philosophical foundation which Gadamer (1976) says is often lacking when phenomenology is used strictly as a method and not as an orienting framework for research. Phenomenology presents itself as suitable for this study because of its history of use with correctional populations and because the lived 
experience of mandatory education participants is sought as a basis for possible fiscal policy determinations regarding educational programming.

The Thomas and Pollio (2002) model is in use weekly throughout the year by the Existential Hermeneutic Phenomenological Research Group (referred to here as the "research group") composed of faculty and students in a university in the southeast who form a hermeneutic circle to collaboratively discover themes in qualitative interviews that speak to the essence of the particular phenomenon being studied. Figure 1 illustrates the basic steps of the model which include: (a) conducting and transcribing interviews, (b) analyzing data for thematic units, and (c) developing a thematic structure. The thematic structure depicts the essence of the experience and consists of figural themes that are different aspects of the experience that stand out against a background or ground that makes the themes visible.

Figure 1. Summary of steps in conducting an existential-phenomenological study 


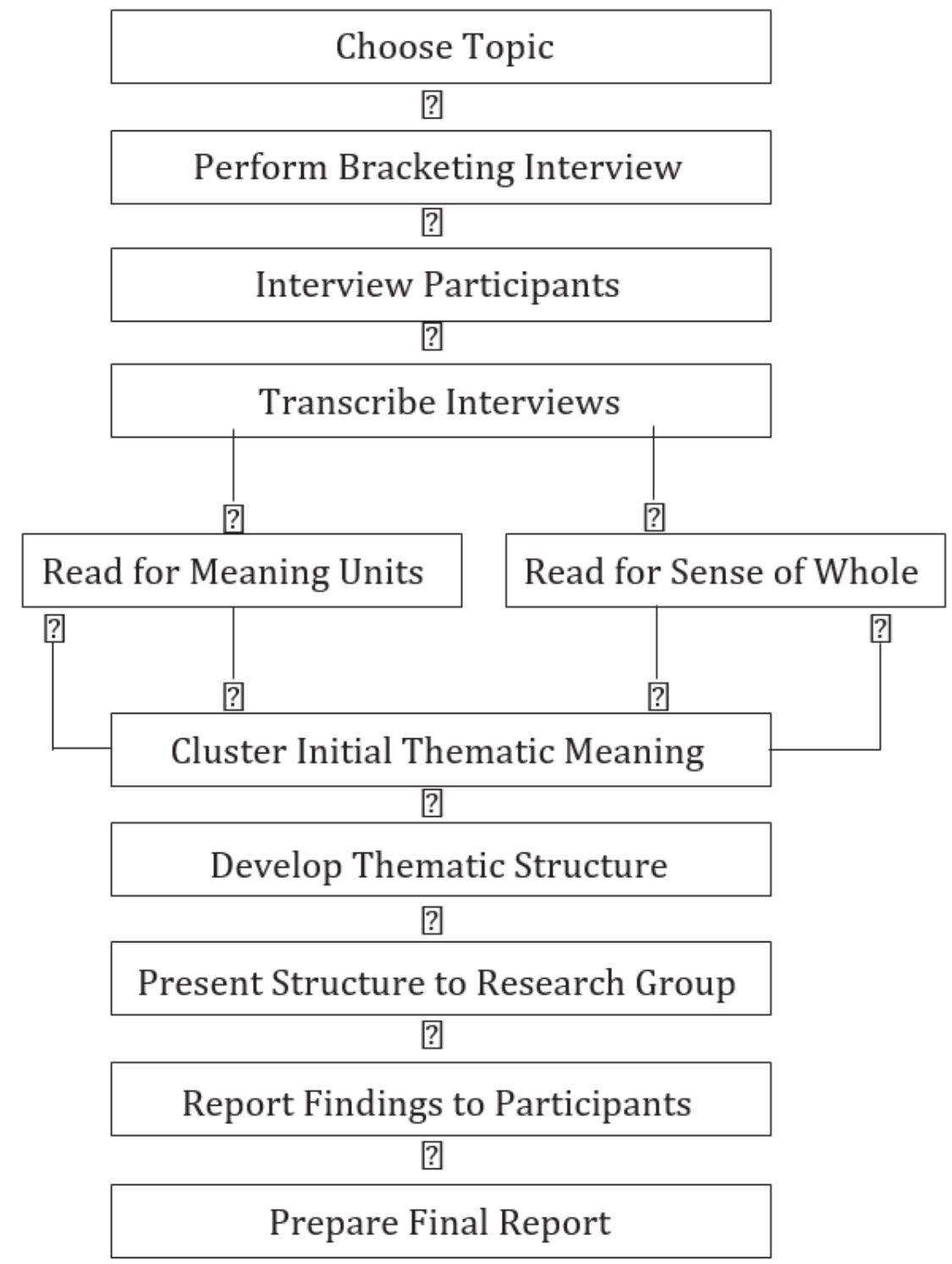

Self as Focus

Participants as Focus

Text as Focus

(Hermeneutic Analysis Part-toWhole Dialectic)

All (Most) Analyses Are Done Within Context of Research Group

Participant as Focus

Research Community as Focus

Phenomenological methods such as the one used in this study allow the researcher to analyze the data in a way that seeks to describe the mean ing of a particular experience rather than to generate a theory. In existential phenomenology, the essence of the experience is considered to be co-created from figure and ground (Thomas \& Pollio, 2002). That is, experience is contextualized making the experience figure and the context of the experience, ground (Thomas \& Pollio, 2002). Four major existential grounds (time, body, world, and others) serve as the backdrop from which figures are developed. All experiences are grounded in the world, but what stands out in that experience is a figure based upon individual perception. By capturing the figure/ ground relationship in existential phenomenology, we can begin to understand the meaning of a particular experience. 
In order to begin understanding the experience of adults required to attend $A B E$ or GED classes as a condition of their probation or parole and to illuminate the experience of a population that hither to has been invisible, we chose the following research question to guide this study: How do adults experience a coerced GED program? We acknowledge that this question may seem especially broad; however, the method of phenomenology that we chose for this study stresses the use of broad questions in order to capture whatever aspects of the particular experience the participant wishes to share. And the question, while broad, deals with the specific population of community corrections clients. In addition, because no previous research had addressed this population, it was expected that this question would give insight into more specific phenomena and generate questions for future research including students' prior experiences with traditional schooling, relationships with teachers, both as adults and non-adults, etc.

\section{Participants}

Participants included nine adult students, eight males and one female who were attending a community-based GED program for individuals serving community corrections sentencesspecifically, probation and parole. The program was administered by the local sheriff's office and funded by the state Board of Probation and Parole. The participants were required by the conditions of their probation or parole to attend GED classes. No non-correctional students were allowed to attend this program. Institutional Review Board approval was obtained before recruiting participants, participation in this study was voluntary, and participants did not receive any compensation for participating in the study. Participants were recruited using fliers in the building where educational classes were conducted and through snowball sampling with students who participated. Because the adults enrolled in the local program were either native English speakers or proficient in English, the fliers were posted in English. Interested participants were instructed to contact the lead researcher, who worked at the facility. Informed consent was collected prior to the interviews. Participants ranged in age from 23 to 38; five identified as Black and four identified as White. We refer to the participants as students because they were actively attending a GED class.

\section{Data collection}

Data for this study included interview data collected through phenomenological interviews with participants and demographic information collected prior to each interview. In a phenomenological study, the interviewer is the primary interview tool, and the participant is the authority on the experience being described. The interviewer should only be responsive to the participant's descriptions "as they unfold in the texture of the conversation" (Thomas \& Pollio, 2002, p. 25). Because of this, questions cannot be asked without the specific subject first being introduced by the participant. Phenomenological research, which deals with the life world of the individual, is quite different from a free flowing interview where the interviewer's curiosity may direct the flow of the 
conversation. Since participants' experiences in the pre-reflective Lifeworld are the subject of phenomenological research, participant recall is not an issue in phenomenology. Similarly, pre- and post-interviewing is not a part of the phenomenological method, because the prereflective experience is what is being sought.

\section{Bracketing}

Prior to interviewing participants, each researcher was interviewed regarding his own experiences with mandatory ABE or GED programs. This practice is commonly referred to as bracketing (Hatch, 2002; Moran, 2000; Polkinghorne, 1989; Pollio, et al. 1997; Thomas \& Pollio, 2002) and is a process in which the researcher acknowledges any a priori theory, assumptions, beliefs, interests, or bias regarding the phenomena at hand (Davis, Mottern and Ziegler, 2010). During our bracketing interviews, we described our experience with mandatory GED programs and any presuppositions they may have had regarding such programs or program participants. This process required us to be transparent regarding our biases and assumptions, making us mindful to avoid asking leading questions during the interviews or to impose unquestioned beliefs on interpretation of the data.

\section{The phenomenological interview}

In a phenomenological interview, questions are not asked about anything participants did not previously introduce into the interview (Kvale, 1983). This relationship is critical to the interview process because the researcher has the responsibility to probe and seek detail while allowing the participant to set the flow of dialogue. To best capture the students' descriptions of their experiences in the GED program, we conducted unstructured interviews using the prompt, "What is your experience in a coerced GED program?"

Use of the word, coerced, was taken from the correctional literature (Baird \& Frankel, 2001; Day, Tucker \& Howells, 2004; Farabee, Prendergast \& Anglin, 1998; Klag, O'Callaghan \& Creed, 2005; Parhar, Wormith, Derkzen \& Beauregard, 2008) and deemed to be less confusing for participants than court-mandated, and less charged than forced. It was thought that there may have been confusion over using the term court-mandated because participation in the GED program may not have been in their court judgment but was required by their community corrections officer as a condition of their probation. Since phenomenology seeks participants' lived experience, prompting them with questions that reflect their experience was deemed more important than using politically correct phrasing. Probing questions were left open-ended to encourage elaboration from the participant (Merriam, 2009). Each of the nine participants participated in one individual interview that was held at the facility where the GED program was conducted. The average length of the interviews was 35 minutes. All interviews were digitally recorded and transcribed by the researchers. All identifying data were removed and participants were assigned pseudonyms. The transcribed, edited, and revised interviews served as the sanitized data set for analysis. 
Because the particular phenomenological method used suggests that the essence of an experience can be gleaned from relatively few participants, the data from the nine interviews were sufficient to achieve data saturation. While there is no consensus in phenomenological research on what constitutes data saturation, Thomas and Pollio (2002) identify saturation as occurring when already identified themes are being repeated, and no new themes are emerging from the data. Saturation occurred with seven participants and, using the $\mathrm{n}+2$ rubric, two additional interviews were conducted to see if new themes emerged. No new themes appeared in the data.

While high participant numbers (n) are characteristic of quantitative studies and other types of qualitative research, phenomenological theory makes it clear that when phenomenological methodology is followed, i.e., bracketing, description of the phenomenon being studied (which includes the use of free imaginative variation), description of the discovered eidae (essences), these eidae may be described from a population of one (Giorgi, 2007; Solomon, 1972). In other types of research, high numbers of participants are thought to extend generalizability; however, phenomenological research is inherently generalizable (Husserl, 1901/2000; Giorgi, 1997; Giorgi, 2008). Thomas and Pollio (2002) describe generalizability in existential hermeneutic phenomenology (the guiding model of this research):

The case for what might be called phenomenological generalizability is different [from that used in quantitative methods]. Here, "proof" does not depend solely on purity of method but also upon the reader of the research report. In this case, when and if a description rings true, each specific reader who derives insight from the results of a phenomenological study may be thought to extend its generalizability. Unlike other research methods where the researcher establishes generalizability on the basis of statistical and experimental procedures, phenomenological research is "validated" by its readers. (p. 42)

This generalizability extends, also, to race and gender of the participants. Phenomenology describes eidae, which transcend the personal details of the participants. While further research with individuals of different genders and races may extend the generalizability of the study, such extension has nothing to do with race or gender, but with expansion of different themes within the Lifeworld. The only criteria for inclusion in a phenomenological study is experience of the phenomenon under investigation.

This study is not unique in using low numbers in phenomenological research since, as previously explained, phenomenological research is different from other types of research in how it approaches generalizability (the intrinsic " $n$ " concern). Peer-reviewed publications that embrace phenomenological theory and methodology do not tend to have an issue with low participant numbers. George and Thomas (2010) used 8 participants in their research, and Speraw (2009) used a single participant in her study. Other peer-reviewed, phenomenological studies have used less that 12 
participants (Davis, 2005; Gearity \& Murray, 2011; Gibbons, Woodside, Hannon, Sweeny \& Davison, 2011; Secrest, Iorio \& Martz, 2005).

\section{Data analysis}

A phenomenological-hermeneutical approach was taken to analyze the data. This was consistent with the underlying phenomenological theory and methodology used to examine the lived experience of the participants. Initial analysis began during transcription of the interviews. We presented two selected transcripts to the research group for feedback. Twelve to fifteen members of the research group analyzed these selected transcripts. We, the researchers, continued to analyze the two transcripts shared with the group as well as the remaining seven transcripts. The transcripts were placed in a file sharing program where we could collaboratively review, code, and comment on the data. Since we approached the data from differing educational perspectives, data analysis was a process of negotiation. First, in vivo and descriptive codes were used (Saldaña, 2009), then potential themes were color-coded. In vivo codes were derived directly from the language used by the participants in the course of interviews (Saldaña, 2009; Strauss, 1987). A descriptive code is a short word or phrase that summarizes the topic of the data passage (Saldaña, 2009). These methods of coding allowed us to look at nested themes and visually distinguish thematic similarities and differences. After viewing and reviewing the color-coded data, a list of figural themes was presented to the research group. Figural themes were noted and discussed by the group, ensuring each theme was supported by quotes from participant transcripts. Considering experience to be a figure/ground phenomena, we identified the ground and developed a thematic structure from the figural themes identified. The thematic structure, presented in Figure 2, was presented to the research group for analysis, interpretation, and feedback.

Figure 2. Experience in a coerced GED program: Thematic structure 


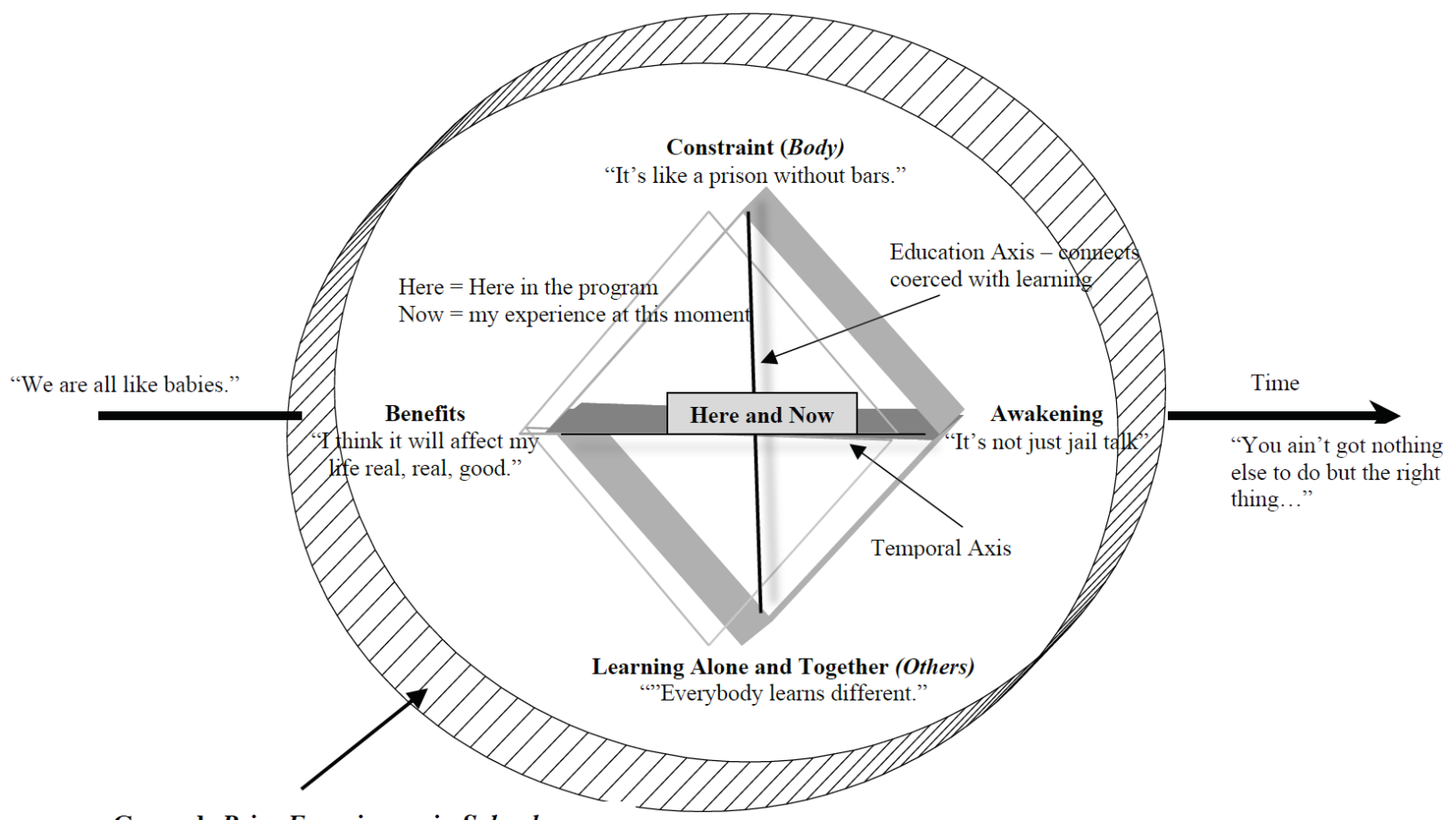

Ground: Prior Experiences in School (world)

\section{Findings}

Drawing upon the collaborative interpretations of the research group's hermeneutic circle, one major ground and four figural themes emerged from the data. The ground of the experience of participating in a mandatory GED program was the participants' prior experiences in school. It was from this ground that the essence of the experience was captured with four figural themes that emerged: (a) “It's like a prison without bars," (b) Learning alone and together: "Everybody learns different," (c) "I think it will affect my life real good," and (d) "It's not just jail talk." These themes are dynamic and illustrate how participants' experiences evolved. We chose to represent the figural themes using the students' own words to describe their experiences.

\section{"It's like a prison without bars"}

All students experienced some amount of coercion related to attending the GED program. These experiences ranged from student insight that they needed some coercion, "you gotta push me to do things" (Bob) to the experience of being forced to do something against their will, "I don't believe it should be forced on me" (Greg). Students had insight into their need for external control and, at the same time, showed resentment because of the control. The experience of constraint took three forms. First, the experience was described as a form of punishment. When asked to describe his experience in the program, one participant responded by simply stating, "I hate it" (Greg). Another expressed his experience as a form of punishment by saying, “There ain't nothing I can do about it. They know I don't 
want to be here to do it" (Chuck). That notion of being punished by education was echoed by Greg when he said, "I don't feel like it should be forced on me. I just don't believe it should. I'm 36 years old. I ain't no kid." From their perspective, education was punishment that was imposed by an outside authority against their will.

Although there was a certain amount of resentment at being forced to attend classes, the experience of punishment was strongest when the students first began attending their GED classes. Over time, the experience of being coerced changed and was viewed more positively. Students' experiences changed as they shifted from education as a form of punishment to education as a freely made choice. Some admitted that they might not have been able to make the choice to attend classes on their own. As Bob remarked, "I just needed a little push. I'm glad I'm doing it on my own but I couldn't really do it on my own. I had to do it the other way. I had to get locked up." Similarly, Henry declared, “It's something I didn't want to do but after being here so long doing it, I can see my benefits from doing it." No participant liked the idea of being pushed to engage in an educational activity, yet most students reluctantly admitted that education, particularly earning a GED, was valuable and something they wanted to have. For example, Abby said, "Coming over here, since I've been on probation, has really helped me a whole lot because if I wasn't over here I probably would still not be getting my GED.” The change from viewing education as punishment to reward also occurred because of achievement. "It made me feel messed up at first but whenever I took the first test and passed it, the first moment that I found out that I passed it, that was something that really, really meant a lot to me. I felt it in my heart" (Eric).

Students who said they were resistant at first described how their resistance lessened over time as they interacted with others. In this type of research, the meaning of time is determined by the participants rather than by some objective measure.

\section{"Everybody learns different"}

Students related their experiences with the GED program to their experiences in prior schooling. Data illustrate that the students' perceptions of learning were based on traditional instructional pedagogy, "It's different than I thought it was going to be. I thought there was going to be a teacher standing up, like back in school, like on a chalkboard" (Bob). Another man said, "It's more one-on-one [than regular school]. It helps you more" (Eric). There was an awareness of one's preference for a particular instructional style. "It is complicated for me to like, learn certain things. Everybody's thinking process ain't the same [and] some teachers teach one-way but everybody doesn't learn the same way. Everybody learns different is basically what I'm saying" (Chuck).

Most of the students identified the GED classroom as different from what they expected because they were asked to work independently. This experience was seen on both positive and negative ways. For 
example, Bob believed working alone was an effective way for him to learn. "You'll learn faster if you do it yourself. They've got the tools and you've got to use it, if you want to help yourself. They ain't babysitting you down there, I know that."

In contrast, others did not see the benefits of working independently. "There ain't nobody helping you do nothing. You just get back there in a room by yourself. It's hard to teach yourself if you don't know how" (Greg). This experience of having to teach yourself was a common interpretation of the way the GED classroom was structured. "I don't know how to do what I need to know how to do and I don't really have nobody around to help me learn how to do what I need to know how to do to get the GED. There's not much teaching involved in it and I think it is kind of hard the way it is set up" (Fred).

At times, a student had to ask others for help. "And then sometimes a teacher puts it up there and if you don't get it right then, you don't get it. You better hope you can get with somebody that knew it or whatever" (Doug).

Students expected a more traditional classroom where less independent work took place. GED classrooms are usually structured differently than a traditional high school classroom with less group instruction and more time for independent work. Students had to get used to this type of structure.

\section{"I think it will affect my life real, real, good"}

Students saw that attending the GED class would affect their lives positively. The way their educational experience would affect their lives was experienced in different ways that focused on the present and the future and included maturity, personal achievement, children, and jobs.

Maturity was identified as the outcome of attending GED classes. "I still could be out in the streets, using, you know, doing whatever but this program has helped me to mature a lot" (Abby). This internal sense of growing maturity supported the ability to learn. "I can actually focus now and actually learn like how I want to. When I was young I didn't see that but now I do ... now that I'm grown, I be seeing stuff that I really need" (Chuck). Henry talks about not caring about education because he had never thought about it,

versus the first time I came to now, I think I grew up more. I think it made me realize some things that I never really thought about versus being out there in the streets and just not really caring and thinking you can just do this and get by or do that and get by. You know, when all else fails, you ain't got nothing else to do but the right thing. (Henry)

Along with maturity came a sense of personal achievement for students. Some described this new sense of achievement and acknowledgment of how far they had come, "I'm accomplishing something with what I'm doing and that feels good" (Doug). Education, even when it is forced, is something that most participants saw as valuable. "It's giving me the opportunity to go back and get something that I 
want, my education" (Chuck). Finishing high school or earning a GED has positive implications. "I wasn't able to finish high school so this is my little sense of finishing high school. It means a lot because now I am actually in a position to actually better myself" (Eric).

Those students who had children saw a GED as beneficial because it demonstrated the importance of education. "I wanna do it for myself too and I wanna do it for my children too because I push my kids to do good in school. Getting my GED shows them that education is important" (Adam). Several students with children expressed the hope that their children would learn from them. "I mean I will be able to show my kids I can be a better person, that I am going back to school will make them want to try more in school" (Eric). Henry echoed the importance of demonstrating the value of education. "It's important for me to be a role model for them [his children]."

Another future benefit of earning a GED was the belief that it increased employment opportunity. "I gotta have the GED to get the kind of job I want. You know, most jobs require you to have an education" (Chuck). The idea that better employment is connected to obtaining the GED was pervasive among the participants. "I am actually in a position to actually better myself without being stuck at this dead-end job or that dead-end job. [I'll] be able to look for a better job ... and to go for the jobs that you have to have your high school diploma" (Eric). Even beyond "better jobs" was the idea that one could learn a trade. "I've been in the streets all my life and what I've always wanted to be was an electrician and just to learn new stuff and have a better environment ... I can with my GED” (Bob). Employment with benefits implied stability. "I've got a family now and I'm getting my kids back and the GED is going to help me find stability in my job. I need stability and benefits in my job now. It ain't like I'm by myself anymore" (Adam).

The participants' expectations regarding the benefits of a GED are common among adults who return to school (King, 2002; Tyler, 2003). It is not clear whether the participants considered the benefits of a GED before being sanctioned to mandatory education or whether the benefits of a GED is a new understanding that occurred as they attended classes.

\section{"It's not just jail talk"}

Students' experiences in the mandatory GED program indicated that their understanding of education shifted from seeing education as a burden to seeing education as a form of release. "Jail talk" is used to describe what one needs to say in order to avoid trouble while incarcerated. For example, I may tell you I like school, but if that is jail talk, it means I am just saying what I think you want to hear. When students stated that they saw real value in learning and it was not just jail talk, they were saying that they were being honest about their change in perspective on the value of education, generally, and their participation in the GED program, specifically. They described a type of awakening where they came to understand their prior school experiences and the impact of those experiences, "I reckon that 
probably I am more embarrassed [now] because of where I didn't learn nothing when I was going to school" (Greg). The idea of not learning while one was in school was a common theme. "[I am learning] a lot of things that I had forgot in school. It's helped me to go back to some things really that I never did see when I was going to school" (Abby). Either "things" were learned in school and forgotten or they were never learned because of a wide variety of reasons. "A lot of stuff I didn't learn while in school, I get the chance to learn it [now] and it's a great accomplishment for me" (Doug). Although most students took responsibility for not learning in school, Bob realized that school played a role in his failure. “To me, I think the teachers just moved me up to get me out of the way, you know what I'm saying. Because I was skipping school and I was just doing everything I wasn't supposed to do. That's why I didn't learn nothing" (Bob). Finally, Eric and Henry describe coming to the realization about how difficult it is to succeed in the world without an education.

I've always heard people say, Do good in school because you are going to need it later.

But I didn't really look at it that way. I didn't feel like I needed it that way until actually getting out in the main world and seeing how hard it really is with no education or no trade or nothing up under your belt. (Eric)

Because the participants are in the GED program due to having a criminal record, they have an increased awareness of the consequences of their actions.

Most of us didn't really want to go to school. Most of us turned to the streets and, you know, instead of going to school we was in the streets. You know, you're out there making money-four or five hundred dollars a night-two or three thousand dollars a week. What do you need school for? Then, after you get in trouble for doing what you're doing, you think about it. It's either straighten up and fly right or go to the penitentiary. (Henry)

Even those who said that being a mandatory GED class as a less than a positive experience talked about how their experience was more than just jail talk because they had come to a new understanding of themselves and education.

The themes show that the experience of being in a mandatory GED program has an evolving nature. It begins as resentment and resistance and evolves over time into the potential of a positive experience that some participants say they would now freely choose because they see the benefit of education and experience a sense of achievement.

\section{Discussion}

Findings from this study address a research gap in community-based correctional education. Neither the correctional literature not the adult education literature has focused on adults in community-based corrections who are forced to attend GED classes. Forcing adults to learn is almost the antithesis of 
adult education principles such as voluntary participation (Houle, 1961; Knowles, 1970). Yet mandatory education is growing as part of the legal system's post-incarceration requirements, and this growth is affecting local $A B E$ and GED programs. Since very little is known about community-based correctional education from the students' point of views, the purpose of this study was to understand the experience of adults who are required to attend $A B E$ or GED classes as a condition of their probation or parole. The findings describe their experience. In existential phenomenological research, experience is seen against a ground or background. The ground of the experience was the participants' prior experiences in school. Each theme describes an aspect of the experience and stands out against this background. The first theme, "it's like a prison without bars," was seeing education as a constraint to freedom. Next was "everyone learns different," which meant adjusting to the different structural and instructional demands of a GED class compared to a more traditional high school environment. "I think it will affect my life real, real good" noted the potential benefits that the experience of attending a GED in the present, in terms of their maturity and in the future in terms of their opportunity for advancement. Finally, "it's not just jail talk" signified an awakening about their lack of education and the potential consequences of not following the mandate of the court.

Findings from the study challenge Jenkins (2002) and Ryan and McCabe (1994) who contend that educational success is only achieved through voluntary participation. Other research shows that coerced learners often have positive outcomes (Landenberger \& Lipsey, 2005; Mackenzie, 2000; Wilson, Bouffard \& Mckenzie, 2005). Participants in this research were legally forced to attend classes, and although they resisted this coercion at first, most eventually saw the benefits of their educational experience, as evidenced by the themes "I think it will affect my life real, real good" and “It's not just jail talk." The findings support DiVito's (1991) contention that education increases the desire for more productive citizenship.

As the literature suggests (Crime and Justice Institute, 2009; Dowden \& Andrews, 2000), the experience described by the participants indicates that they definitely have a desire to be more productive citizens because they want to be qualified for stable jobs and to be role models for their children. While students saw benefits from engaging in educational studies and earning their GEDs, they recognized that they were not able to make the decision to attend education classes on their own. While being coerced was seen as negative at first, this changed over time. The self-knowledge that "you gotta push me" showed that not everyone volunteers to do what they know is in their best interest. This need for a push is consistent with Flowers (2000) who demonstrated that a motivating factor for continued participation comes from being mandated by the courts. This is a challenge to many GED programs that are structured to provide individualized instruction for self-directed learners. Educators who expect students to be self-directed when they enter a GED program may be frustrated (Warner, 2007). This frustration may be exacerbated by students' expectations of how 
learning should take place since their understanding is primarily based on prior experiences they had in school, and for many, these experiences were negative.

Against the ground of prior experience of school, the notion "they ain't babysitting you down here" revealed that students' conceptions of learning are based in typical pedagogical traditions. Because

prior learning context plays a major role in the expectations of the GED classroom (Belzer, 2004), a violation of expectations can occur that creates a negative learning experience for some of the students. Community-based correctional education programs make it possible for offenders to serve their sentences outside of a prison environment. The ultimate goal of most of these programs is to reduce recidivism by providing the services that help individuals find and keep a job and live productively in the community (Stohr, Walsh, \& Hemmens, 2008). What contrasts the experience of adults in community-based correctional education with their counterparts who are incarcerated is that those in the community must fit their educational activities into their other adult responsibilities. According to the U.S. Department of Education (2011), "Students' lack of motivation and competing demands seem to be the most common and pressing challenges these programs face" (p. 21). Although findings from this study show that students in community-based correctional programs undergo a change in thinking while engaged in the program, the question of lack of motivation remains an area where more research is needed.

\section{Implications for correctional education}

Findings from this study have theoretical implications as well as practical implications for instructional practice and policy. Theoretical implications include the value of coercion in correctional adult education and what working with community corrections students tells us about andragogy and selfdirected learning - the "pillars of adult learning theory" (Merriam, 2001). While adult education theory views adult learners as coming to the classroom as volunteers, this research indicates that forced attendance (i.e., extrinsic motivation) in adult education with court-mandated learners is not only often effective but is also appreciated at some level by the learners. Persistence literature (Comings, Parrella \& Soricone, 1999; McGivney, 2004) states that education is a self-directed experience, and adult educators should find ways to help learners persist in their educational goals. Our research suggests that goals other than educational attainment, e.g., avoidance of negative consequences for failure to attend educational classes, may also be effective in helping some adult students persist in education. This is consistent with other drug-treatment literature (Rempel \& Destefano, 2001; Siddall \& Conway, 1988) that has found court-mandated treatment to be effective.

While the participants did not identify a specific turning point(Abbot, 1997) or epiphany (Denzin, 1989) in their view of education, they did mention familial obligations as influencing their perception of education. This is similar to findings by Laub and Sampson (1993) that adult social bonds to the work force and marriage may bring about changes in criminal behavior. Findings in the current research 
suggest that perceptions about education change and a kind of turning point does occur in students' attitudes about being mandated to attend educational classes. Students do see the benefits of formal studies. With regard to instruction, the findings are particularly relevant for the instructors and programs providing educational services through community-based correctional education programs. In planning mandatory education programs for adult learners in community corrections programs, understanding how students experience coercion has the potential to benefit the planning process because programs and classes can be designed to lessen resistance and increase enthusiasm. Students who are mandated to attend GED classes may be different from students who volunteer to continue their education because volunteers have the freedom to choose whether or not to remain in the program; coerced students do not have the same freedom. They begin by seeing education as punishment. While participants may be openly resistant to attending classes, they may simultaneously want to achieve educationally, particularly with reference to earning their GED, because of the hope that the credential will increase their opportunities. Students may have preconceptions about what the experience of a GED class will be like, and these preconceptions might negatively influence their ability to participate effectively. Non-traditional education is an unfamiliar experience for many students. Like most adult basic educators, instructors and program planners in community corrections programs mandatory education programs need to take into account past educational experiences along with the uniqueness and diversity of this particular population when planning instruction. It is possible that students might benefit from an orientation to self-directed learning. This may be particularly true for students who are mandated to attend class and are mixed in with students who volunteer to attend class.

At the program level, professional development for instructors may help them address the unique needs of these learners. "Currently, most community-based correctional education programs do not provide specific training related to serving individuals under community supervision" (U. S. Department of Education, 2011, p. 25). This is particularly important because adult students in these programs face many challenges and have diverse learning needs compared to students in voluntary programs.

On a policy level, the data findings are alarming - 1 in 45 adults are in a community-based correctional program. Those who view mandatory education programs as being too costly for states (Di Vito, 1991) are shortsighted. Although education is not a panacea, research shows that there is a link between participation in educational programs and a lower recidivism rate (Jensen \& Reed, 2007; Nutall, 2003; Roy, 2004; Steurer \& Smith, 2003; Zgoba, Haugebrook, \& Jenkins, 2008). Unfortunately, research has been conducted primarily with those who attended educational programs while they were incarcerated. "Yet, little is known about the effects of those same services offered in the community to those on parole or probation" (U.S. Department of Education, 2011, p. 27). This study provides a small glimpse into the experience of adult students in mandatory education programs and highlights the 
need for further research. What data are needed to convince policy makers of the viability of community-based correctional education programs? What are the outcomes of participants after they have completed their sentences? These and other questions are critical for addressing this growing area of adult education. Though our study was not designed to compare students in different settings, we see it as a springboard for future research comparing mandatory and voluntary adult basic education programs.

\section{Limitations of the study}

Discussing the limitations of the study requires a confident understanding of phenomenological methodology. A common misinterpretation of phenomenological research is that a larger or more varied sample will lead to more reliable findings (Lester, 1999). While we acknowledge that nine participants might be considered a limited sample, this is not the case in phenomenological research, since it is not designed to produce a statistically reliable sample that reflects the population, but rather to generalize the essence of experience attending GED classes in a community-based correctional education program.

We also acknowledge that it might have been beneficial to have interviewed participants more than once to probe more deeply into their experience, however, individuals who are volunteering and who may be pressured for time may be unable or unwilling to contribute more than an hour to an interview and compromise is required on the part of the researchers to use the time with the participant to probe deeply into their experiences. Indeed, obtaining even a single interview was often futile. Several individuals who indicated their willingness to participate in the study did not arrive for the scheduled interviews, even though the meetings were scheduled at their convenience. They did not contact the researchers after failing to attend their appointments and did not indicate the reasons for their absence.

This particular study is also limited by the absence of a more complete demographic profile for the participants. While this information is unrelated to the phenomenon under investigation, it is a loss of data, data that could be used to relate this phenomenological study to other qualitative and quantitative studies.

\section{Conclusion}

Adults who attend community-based correctional programs as a condition of their parole or probation face many challenges and are an important population to include in adult basic education literature. Findings from our research describe the experience of being forced to attend a GED program. This study illuminates the students' experiences of being pushed and suggests that they value the idea of being productive citizens and eventually admit that education can play a role in achieving this goal. This is an area that needs more research as mandatory education is becoming more common; its focus 
cannot be ignored just because the concept of involuntary participation in adult education does not fit more time-tested models of who adult learners are (Knowles, 1970, 1973) or the expectations educators may have about the students because they are adults. These tensions provide all the more reason to address the needs and experiences of this unique population. Doing so also paves the way for future research with instructors and program planners in community corrections mandatory education programs. We conclude there is much to be learned from the experience of the students, practitioners, and stakeholders in these growing programs.

\section{References}

Abbot, A. (1997). On the concept of turning point. Comparative Sociological Review, 16, 85-105.

Anderson, S. V. (1995). Evaluation of the impact of correctional education programs on recidivism. Retrieved from http://www.ncjrs.gov/App/Publications/ abstract.aspx?ID=174087

Andrews, D. A., \& Bonta, J. (1995). The Level of Supervision Inventory-Revised. Toronto, Canada: MultiHealth Systems.

Andrews, D. A., \& Bonta, J. (2001). LSI-R user's manual. Toronto, Ontario, Canada: Multi-Health Systems, Inc.

Andrews, D. A., \& Bonta, J. (2006). The psychology of criminal conduct (4th ed.). Cincinnati, OH: Anderson.

Andrews, D. A., Bonta, J., \& Wormith, J. S. (2006). The recent past and near future of risk and/or need assessment. Crime \& Delinquency, 52 (1), 7-27.

Andrews, D. A., Zinger, I., Hoge, R. D., Bonta, J., Gendreau, P., \& Cullen, F. T. (1990). Does correctional treatment work? A clinically relevant and psychologically informed meta-analysis. Criminology, 28(3), 369-404.

Aos, S. (1998). Watching the bottom line: Cost-effective interventions for reducing crime in Washington. Washington State Institute for Public Policy. Olympia, WA.

Bahn, C., \& Davis, J. R. (1998. Day reporting centers as an alternative to incarceration. Journal of Offender Rehabilitation, 27(3), 139150.

Baird, f. x., \& frankel, A. J. (2001). The efficacy of coerced treatment for offenders. Journal of Offender Rehabilitation, 34(1), 61-80.

Belzer, A. (2004). "It's not like normal school": The role of prior learning contexts in adult learning. Adult Education Quarterly, 55(1), 41-59. 
Bonta, J. (1996). Risk-needs assessment and treatment. In A. T. Harland (Ed.), Choosing correctional options that work: Defining the demand and evaluating the supply (pp. 18-32). Thousand Oaks, CA: Sage.

Bonta, J., \& Andrews, D. A. (2007). Risk-need-responsivity model for offender rehabilitation. Retrieved from http://securitepubliquecanada.gc.ca/res/cor/rep/_fl/risk_Need_2007-06_e.pdf

Brewster, D. R., \& Sharp, S. F. (2002). Educational programs and recidivism in Oklahoma: Another look. The Prison Journal, 82(3), 314-334.

Butler, T., Andrews, G., Allnut, S., Sukashita, C., Smith, N. E., \& Basson, J. (2006). Mental disorders in Australian prisoners: A comparison with a community sample. Australia and New Zealand Journal of Psychiatry, 40(3), 272-276.

Case, P. F. (2006). Predicting risk time and probability: An assesment of prison education and recidivism. Retrieved from http://www. allacademic.com/ meta/p_mla_apa_research_citation/0/9/5/1/4/pages95149/p95149-1.php

Casey, P., \& Rottman, D. B. (2000). Therapeutic jurisprudence in the courts. Behavioral Sciences $\mathcal{E}$ the Law, 18(4), 445-457.

Chavaria, F. R. (1997). Probation and cognitive skills. Federal Probation, 61(2), 57-60.

Chavez, R., \& Dawe, S. (2007). International research trends in education and training provision in correctional settings. In S. Dawe (Ed.), Vocational education and training for adult prisoners in Australia: Research readings (pp. 19-33). Adelaide SA 5000, Australia: National Centre for Vocational Education Research.

Coley, R. J., \& Barton, P. E. (2006). Locked Up and Locked Out: An Educational Perspective on the US Prison Population. Policy Information Report. Educational Testing Service, 34.

Collier, V. P., \& Thomas, W. P. (2001). Educating linguistically and culturally diverse students in correctional settings. Journal of Correctional Education, 52(2), 68-73.

Comings, J. P., Parrella, A., \& Soricone, L. (1999, December). Persistence among adult basic education students in pre-GED classes. NCSALL Report \#12. Boston, MA: National Center for the Study of Adult Learning and Literacy.

Crayton, A., \& Neusteter, S. R. (N.D.). The current state of correctional education paper: A paper presented at the reentry roundtable on education. Retrieved from http://www. jjay.cuny.edu/CraytonNeusteter_FinalPaper.pdf 
Creswell, J. W. (2007). Qualitative inquiry and research design: Choosing among five approaches (2nd ed.). Thousand Oaks, CA: Sage.

Crime and Justice Institute at Community Resources for Justice (2009). Implementing evidence-based policy and practice in community corrections, 2nd ed. Washington, DC, National Institute of Corrections.

Davis, C.A., Mottern, R., \& Ziegler, M.F. (2010). “It's like a prison without bars”: Experiences in a mandatory GED program. In P. Gandy, S. Tieszen, C. Taylor-Hunt, D. Flowers, \& V. Sheared (Eds). 51st Adult Education Research Conference (AERC) and 3rd Western Region Research Conference on the Education of Adults (WRRCEA) Joint Conference Proceedings. (pp. 115-121). Sacramento, CA: California State University.

Davis, L. A. (2005). A phenomenological study of patient expectations concerning nursing care. Holistic Nursing Practice, 19(3), 126-133.

Day, A., Tucker, K., \& Howells, K. (2004). Coerced offender rehabilitation-a defensible practice? Psychology, Crime \& Law, 10(3), 259-269.

Denzin, N. K. (1989). Interpretive interactionism. Newbury Park, CA: Sage.

Di Vito, R. J. (1991). Survey of mandatory education policies in state penal institutions. Journal of Correctional Education, 42(3), 126-132.

Dowden, C., \& Andrews, D. A. (2000). Effective correctional treatment and violent reoffending: A metaanalysis. Canadian Journal of Criminology, 451(2000), 449-467.

Farabee, D., Prendergast, M., \& Anglin, M. D. (1998). The effectiveness of coerced treatment for drugabusing offenders. Federal Probation, 62(1), 3-10.

Flowers, S. (2000). Understanding the learner who is court-mandated to learn. Practitioner Research Briefs. 1999-2000 Report Series: Virginia Adult Educators Research Network, Dayton.

Folsom, J., \& Atkinson, J. L. (2007). The generalizability of the LSI-R and the CAT to the prediction of recidivism in female offenders. Criminal Justice and Behavior, 34(8), 1044-1056.

Frank, J. B. Omstead, J. A., \& Pigg, S. A. (2012). The missing link: Servicelearning as an essential tool for correctional education. Journal of Correctional Education, 63(1), 24-34.

Gadamer, H. G. (1976). Philosophical hermeneutics. Berkeley, CA: University of California Press. 
Gearity, B. T., \& Murray, M. A. (2011). Athletes' experiences of the psychological effects of poor coaching. Psychology of Sport and Exercise, 12 (3), 213-221.

Gehring, T. (2000). Recidivism as a measure of correctional education program success. Journal of Correctional Education, 51(2), 197-205.

Gendreau, P., Little, T., \& Goggin, C. (1996). A meta-analysis of the predictors of adult offender recidivism: What works! Criminology, 34(4), 575607.

George, S. R., \& Thomas, S. P. (2010). Lived experience of diabetes among older, rural people. Journal of Advanced Nursing, 66, 1092-1100.

Gibbons, M. M., Woodside, M., Hannon, C., Sweeney, J. R., \& Davison, J. (2011). The lived experience of work and career: Women whose parents lack postsecondary education. Career Development Quarterly, 59(4), 315-329.

Giorgi, A. (1997). The theory, practice, and evaluation of the phenomenological method as a qualitative research procedure. Journal of Phenomenological Psychology, 28(2), 235-260.

Giorgi, A. (2007). Concerning the phenomenological methods of Husserl and Heidegger and their application in psychology. Collection du Cirp, 1, 63-78.

giorgi, A. (2008). Difficulties encountered in the application of the phenomenological method in the social sciences. Indo-Pacific Journal of Phenomenology, 8(1).

Glaze, L. E., \& Parks, E. (2012). Correctional populations in the United States, 2011. Retrieved from http://bjs.ojp.usdoj.gov/content/pub/pdf/cpusl1.pdf

Gordon, H. R. D., \& Weldon, B. (2003). Impact of career and technical education programs on adult offenders: learning behind bars. Retrieved August 31, 2009 from http://www.ncjrs. gov/App/ Publications/abstract.aspx ID $=203952$

Gornik, M. (2002). Moving from correctional program to correctional strategy: Using proven practices to change criminal behavior. The ICCA Journal on Community Corrections, April, 24-33.

Gunnison, E., \& Helfgott, J. B. (2011). Factors that hinder offender reentry success: A view from community corrections officers. International Journal of Offender Therapy, 55(2), 287-304.

Guy, T. (2005). A phenomenological analysis of the lived experiences of adolescent female delinquents deterred in a correctional treatment facility with a reported history of sexual abuse (Doctoral dissertation). St. Mary's University, San Antonio, TX. 
Harper, G., \& Chitty, C. (2005). Impact of corrections on reoffending: A review of "What Works." Retrieved from http://www.homeoffice.gov.uk/rds/pdfs04/hors291.pdf

Hatch, J. A. (2002). Doing qualitative research in education settings. Albany, N.Y.: State University of New York Press. Hatch, J. A. (2002). Doing qualitative research in education settings. Albany, N.Y.: State University of New York Press.

Heidegger, M. (1927/1962). Being and time. (J. Macquarrie, \& E. Robinson, Trans.). New York, NY:Harper Perennial.

Helfgott, J. B., \& gunnison, e. (2008). The influence of social distance on community correction officer perceptions of offender reentry. Federal Probation, 72(1), 2-12.

Hollin, C. R. (1999). Treatment programs for offenders meta-analysis, "What Works," and beyond. International Journal of Law and Psychiatry, 22(3-4), 361-372.

Houle, C. O. (1961). The inquiring mind: A study of the adult who continues to learn (2nd ed.). Madison, WI: The University of Wisconsin Press.

Hubbard, D. J., \& Latessa, E. J. (2004). Evaluation of cognitive-behavioral programs for offenders: A look at outcome and responsivity in five treatment programs. Retrieved from http://www.uc.edu/criminal Husserl, E. (1900/2001). Logical Investigations vol. 1. (J. N. Findlay, Trans.) London, UK: Routledge. Jenkins, D. (2002). The potential of community colleges as bridges to opportunity for the disadvantaged: Can it be achieved on a large scale? Chicago, IL: Illinois University.

Jensen, E. L., \& Reed, G. E. (2007). Adult correctional education programs: An update on the current status based on recent studies Journal of Offender Rehabilitation, 44(1), 8198.

Kennedy, S. M. (2000). Treatment responsivity: Reducing recidivism by enhancing treatment effectiveness. Retrieved from http://epe.lac-bac.gc.ca/100/200/301/csc-scc/ compendium_2000e/text/rsrch/compendium/2000/chap_5_e.shtml

King, C. (2002). Barriers affecting GED participation among recent high school dropouts. Adult Basic Education, 12 (3), 145-156.

Klag, S., O'Callaghan, F., \& Creed, P. (2005). The use of legal coercion in the treatment of substance abusers: An overview and critical analysis of thirty years of research. Substance Use \& Misuse, 40, 17771795.

Knowles, M. S. (1970). The modern practice of adult education. Chicago, IL: Association Press. 
Knowles, M. S. (1973). The adult learner: A neglected species. Houston, TX: Gulf Publishing.

Kvale, S. (1983). The qualitative research interview. Journal of Phenomenological Psychology, 14, 171-196.

Landenberger, N. A., \& Lipsey, M. W. (2005). The positive effects of cognitive-behavioral programs for offenders: A meta-analysis of factors associated with effective treatment. Journal of Experimental Criminology, 1(4), 451-476.

Laub, J. H. \& Sampson, R. J. (1993). Turning points in the life course: Why change matters to the study of crime. Criminology, 31(3), 301-326.

Lester, S. (1999). An introduction to phenomenological research. Taunton, UK: Stan Lester Developments.

Little, G. L., Robinson, K. D., \& Burnette, K. D. (1994). Treating offenders with cognitive-behavioral therapy: 5-year recidivism outcome data on MRT. Cognitive-Behavioral Treatment Review, 3, 1-3.

MacKenzie, D. L. (2000). Evidence-based corrections: Identifying what works. Crime \& Delinquency, $46(4), 457-471$.

Mageehon, A. (2006). What makes a "good" teacher "good"? Women in transition from prison to community reflect. Journal of Correctional Education: Correctional Education Association.

Marion, N. (2002). Effectiveness of community based correctional programs: A case study. The Prison Journal, 82(4), 478-497.

McGivney, V. (2004). Understanding persistence in adult learning. Open Learning, 19(1), 33-46.

Merleau-Ponty, M. (2002). Phenomenology of perception (C. Smith, Trans.). New York, NY: Routledge. (Original work published 1945.)

Merriam, S. B. (2001). Andragogy and self-directed learning: Pillars of adult learning theory. New Directions in Adult and Continuing Education, 89, 3-13.Merriam, S. B. (2009). Qualitative research: A guide to design and implementation. San Francisco: Jossey-Bass.

Merriam, S. B. (2009). Qualitative research: A guide to design and implementation. San Francisco: JosseyBass.

Moeller, M., Day, S. L., \& Rivera, B. D. (2004). How is education perceived on the inside?: A preliminary study of adult males in a correctional setting. Journal of Correctional Education, 55(1), 40-59.

Montross, J. F., \& Montross, K. J. (1997). Characteristics of adult incarcerated students: Effects on instruction. Journal of Correctional Education, 48(4), 179-186. 
Moran, D. (2000). Introduction to phenomenology. New York: Routledge.

Mottern, R. D. (2011). "Your world stops": The relationship chiasm between teachers and students in court-mandated adult education.

Nethavhani, M. J. (2002). A phenomenological study of rehabilitation of serious juvenile offenders. Retrieved from htps://ujdigispace.uj.ac.za/ handle/10210/1617

Nuttall, J. (2003). The effect of earning a GED on recidivism rates. Retrieved from http://jlaptop.passged.com/media/pdf/research/The_Effect_ of_Earning_a_GED_on_Recidivisim_Rates.pdf

Parhar, K. K., Wormith, S., Derkzen, D. M., \& Beauregard, A. M. (2008). Offender coercion in treatment: A meta-analysis of effectiveness. Criminal Justice and Behavior, 35(9), 1109-1135.

Pollio, H.R. Henley, T., \& Thompson, C.B. (1997). The phenomenology of everyday life. New York: Cambridge University Press.

Polkinghorne, D. E. (1989). Phenomenological research methods. In R. S. Valle \& S. Halling (Eds.), Existential-phenomenological perspectives in psychology: Exploring the breadth of human experience (pp. 4160). New York: Plenum Press.

Puloka, E. (2012). A frame analysis of probation and parole officer attitudes and perceptions of reentrants (Masters thesis). Washington, D.C.: American University.

Rempel, M., \& Destefano, C. D. (2001). Predictors of engagement in courtmandated treatment: Findings at the Brooklyn Treatment Court, 1996-2000. Journal of Offender Rehabilitation, 33(4), 87-124.

Roy, S. (2004). Factors related to success and recidivism in a day reporting center. Criminal Justice Studies, 17(1), 3-17.

Ryan, T. A., \& McCabe, K. A. (1994). Mandatory versus voluntary prison education and academic achievement. The Prison Journal, 74(4), 450461.

Saldaña, J. (2009). The coding manual for qualitative researchers. Thousand Oaks, CA: Sage.

Sayko, E. A. (2005). The making of a prison teacher: A phenomenological journal through the lived experiences of correctional educators (Doctoral dissertation). Retrieved from http://drum.lib.umd.edu Secrest, J., Iorio, D. H., \& Martz, W. (2005). The meaning of work for nursing assistants who stay in long-term care. Journal of Clinical Nursing, 14, 90-97. 
Sherman, L. W., Gottfredson, D., MacKenzie, D., Eck, J., Reuter, P., \& Bushway, S. (1998). Preventing crime: What works, what doesn't, what's promising. Retrieved from http://www.acro.com.au/Reports/Sherman\%20Preventing\%20Crime.pdf

Siddall, J. W., \& Conway, G. L. (1988). Interactional variables associated with retention and success in residential drug treatment. International Journal of the Addictions, 23, 1241-1254.

Sohn, B. (2002). Are young people in correctional institutions different from community students who have never been convicted?: Differences in internalizing and externalizing behavior. British Journal of Social Work, 33(6), 739-752.

Solomon, R. C. (1972). Introduction: What is phenomenology. In R. C. Solomon (ed.), Phenomenology and existentialism. Lanham, MD: Rowman \& Littlefield.

Speraw, S. (2009). "Talk to me-I'm human": The story of a girl, her personhood, and the failures of health care. Qualitative Health Research, 19(6), 732-743.

Steuer, S., \& Smith, L. (2003). Education reduces crime: Three-state recidivism study. Executive summary: Lanham, MD: Correctional Education Association.

Stohr, M., Walsh, A., \& Hemmens, C. (2008). Corrections: A text/reader: Sage. Strauss, A. L. (1987). Qualitative analysis for social scientists. Cambridge: Cambridge University Press.

The Pew Center on the States (2008) http://www.pewcenteronthestates. org/uploadedFiles/ 8015PCTS_Prison08_FINAL_2-1-1_FORWEB.pdf

Thomas, S. P., \& Pollio, H. R. (2002). Listening to patients: A phenomenological approach to nursing research and practice. New York: Springer Publishing Company

Tordes, L., \& Holloway, I. (2010). Phenomenological research. In K. Gerrish, \& A. Lacey (Eds.), The research process in nursing (6th ed.) (pp. 177187). New York, NY: Wiley-Blackwell.

Tyler, J. H. (2003). economic Benefits of the geD: Lessons from recent Research. Review of Educational Research, 73(3), 369-403.

United States Department of Education (2011). Community-based correctional education. http://www2.ed.gov/about/offices/list/ ovae/pi/AdultEd/cbce-report-2011.pdf

Van Manen, M. (1990). Researching lived experience: Human science for an action sensitive pedagogy. New York: State University of New York. 
Warner, K. (2007). Against the narrowing of perspectives: How do we see learning, prisons and prisoners? Journal of Correctional Education, 58(2), 170-184.

West, R. J. (2011). Post-correctional education interventions: A phenomenological case study of empowerment education curriculum for formerly incarcerated African American males. Retrieved from http://ecommons.luc.edu/luc_diss/41

Willig, C. (2007). reflections on the use of the phenomenological method. Qualitative Research in Psychology, 4(3), 209-225.

Wilson, D. B., Bouffard, L. A., \& Mckenzie, D. L. (2005). A quantitative review of structured, grouporiented, cognitive-behavioral programs for offenders. Criminal Justice and Behavior, 32(2), 172-204.

Woods, R. (2010). Synchronicity and transformation in the experience of prison educators (Doctoral dissertation). Walden University, Ann Arbor, MI.

Yochelson, S. \& Samenow, S. (1976). The criminal personality (3 vols.). New York, NY: Aronson.

Zgoba, K. M., Haugebrook, S., \& Jenkins, K. (2008). The influence of geD obtainment on inmate release outcome. Criminal Justice and Behavior, 35(3), 375-387.

\section{Author Biographies}

Ron Mottern is with the Department of Educational Psychology and Counseling at the University of Tennessee.

C. Amelia Davis, at the time of the research, was with the Department of Educational Psychology and Counseling at the University of Tennessee; she is now with the Department of Curriculum, Foundations, and Reading, Georgia Southern University.

Mary F. Ziegler teaches in the Department of Educational Psychology and Counseling at the University of Tennessee. 